УДК 821.161.2-93.09-054.7(71+73)

Варданян Марина, кандидат філологічних наук, доцент кафедри початкової освіти Криворізький державний педагогічний університет

\title{
«ВІЛЬНИЙ СВІТ» - «СТАРИЙ КРАЙ»: «ДИТЯЧА» СПАДЩИНА ПИСЬМЕННИКІВ УКРАЇНСЬКОЇ ДІАСПОРИ В КАНАДІ ТА США
}

У статті розглядається украӥнська діаспорна література для дітей та юнацтва американського та канадського осередків з позииії Свого - Чужого. У творах виокремлено два основних конщепти: «Вільний Світ» - «Старий Край», щзо втілюють відповідно Канаду й США та Україну. Письменники рефлектують як над загрозами Чужого, так $i$ можливостями, що таке Чуже збуджує, порушуючи тим самим проблеми волі - неволі, асиміляиії, бікультурності, турботи та самоповаги.

Ключові слова: Чужий - Свій, дитяча література, українська діаспора, бікультурність, асимілячія.

The Free World" - "The Old Land»: "The child» heritage of the Ukrainian Diaspora writers of Canada and the USA.

The article deals with Ukrainian Diaspora Literature for children and youth of American and Canadian centers in terms of "the native" and "the alien" concepts. The Ukrainian Diaspora in Canada and the United States is considered to be the widest one. It has also played a leading role 
in the formation and development of the Ukrainian literature for children and youth abroad. It is represented by more than fifty writers. At the same time, the Ukrainian literature for children and youth of the American and Canadian centers has its own peculiarities. Above all it includes the reality, which reflects the way how the Ukrainian exiles have to root being abroad far away from Ukraine over the ocean.

The American and Canadian Diaspora writers represent in their works both the threats of and the possibilities of "the alien", which arise in particular the problems of freedom and slavery, assimilation, biculturalism, care and self-esteem. Therefore, the works clearly show the implementation of two basic concepts: "The Free World" - "The Old Land". In the Ukrainian foreign context, the positive aspect of the alien topos is the personification of Canada and the United States showing the image of a "cleared homeland", with which the artists link the idea of "the Free World". The works of the Diaspora writers contain the universal models of the Ukrainian community, designed to preserve the national identity in a foreign environment.

At the same time, literature and critique for children raises the problem of denationalization and assimilation of Ukrainian children and youth. The Ukrainian Diaspora writers connect the image of the "The Old Land" with the problem of finding their own roots. It has determined the family theme in the works of the Canadian and American Diaspora writers. They often use in their works the set Ukrainian images such as "father's house", "motherland", "community", "land", "village".

In this way, through "the alien" concept and the culture of Canada and America with their rights and opportunities of the freedom of speech, the writers try to reach "the native", considering in the works for children and youth the problems of national identity under new circumstances, such as: "How to be a Ukrainian child born away from the ethnic homeland?". The works form two roles of Ukrainian youth: assimilate and bicultural.

Thus, Diaspora writers combine in their works for children and youth two cultural worldsthe Canadian-American and Ukrainian ones. On the one hand, the realities of foreign countries are represented, and on the other hand, the mental image of Ukraine is presented. Consequently, the thematic searches of Ukrainian writers in Canada and the United States cover the problems of Ukrainian grouping in a foreign country, individual splitting under the influence of assimilation, the family and tradition continuity, serving Ukraine. assimilation.

Key words: the alien - the native, literature for children, Ukrainian Diaspora, bicultural,

Українська діаспора в Канаді й США є однією з найбільш розгалужених. Провідну роль вона відіграла також у становленні й розвитку літератури для дітей та юнацтва в українському зарубіжжі, яка представлена постатями близько п’ятдесяти письменників. У той же час дитяча діаспорна література американського та канадського осередків має свої особливості, що, насамперед, є відображенням тих реалій, у яких довелося укорінюватися вигнанцям 3 України за океаном. Дослідженню такої специфіки на рівні жанровотематичному з позицій Свого - Чужого і присвячена ця стаття. Обрана тема ще не ставала предметом вивчення українських літературознавців. За методологічну основу для аналізу взято праці Б. Вандельфейса, Г. Г. Гадамера, П. Рікера, Е. Саїда, присвячених різних аспектам в осмисленні проблематики 
Чужого, чужини та Батьківщини, критичні та теоретичні розвідки -
А. Горохович, І. Бойківської,
О. Пресіч, а також спогади -
В. Леника, Яра Славутича.

Відштовхуючись від не-Свого як несвободи, пов'язану українською діаспорою з окупацією України більшовицькою владою, у творчості для дітей та молоді письменників українського зарубіжжя, які осіли в США та Канаді, створювався образ «Вільного Світу» як уособлення волі. У такий спосіб через Чуже, культуру Канади та Америки 3 їхнім правом й можливостями свободовисловлювання, письменники ішли до Свого, осмислюючи у творах для дітей та юнацтва питання національної ідентичності за нових обставин, а саме: «як бути українцем дитині, народженій за межами етнічної батьківщини?». Тут йдеться про представників канадського (Іван Боднарчук, С. Кузьменко, Л. Храплива-Щур) й американського (Т. Білецька, Р. Завадович, Олекса Кобець, С. Парфанович, Ганна Черінь) осередків, художні пошуки яких в літературі для дітей та юнацтва відкривали амбівалентне ставлення до Чужого. Як писав про двоїстість досвіду Чужого Б. Вандельфейс: «Він $\epsilon$ загрозливим, оскільки Чуже конкурує зі Своїм, загрожує підкорити його; привабливим - тому, щзо Чуже збуджує можливості, які тією чи інщою мірою є виключеними порядками власного життя» [Вандельфейс 2002 : 35]. У художніх текстах для дітей та молоді українських письменників Чужий є водночас небезпечним для культури Свого, але й творчим. Утім, у творах для дітей не стільки робиться вибір між Своїм і Чужим, скільки спроба їх поєднати.

До переваг чужого світу I. Бойківська у своїх статті про українську молодь в Канаді й Америці відносила: «...можливість жити вільною людиною (чого немає на Рідній Землі); можливість жити в украӥнському середовищі $i$ свобідно визнавати свої начіональні почування та переконання; можливість вивчення чужих мов, здобування освіти, знання $і$ високих позицій в крайнах, де проживаємо, та можливість мати иирокі зв'язки з представниками різних націiй» [Бойківська 1964 : 2]. Тож в українському зарубіжному контексті позитивним аспектом топосу Чужого стало уособлення Канади та США 3 
образом «прибраної батьківщини», 3 яким митці пов’язували ідею «Вільного Світу». Автори у своїх творах для дітей та юнацтва через образи дітей та дорослих підкреслювали як українське походження, так i засвідчували їх відданість новій батьківщині, що ним стали для нащадків Канада й США. Іншими словами, у творах країни нового осідку постають універсальними моделями спільноти української громади, покликаними зберігати національну ідентичність в чужому середовищі.

Водночас, попри захоплення творчою інтелігенцією демократичними засадами названих країн, в дитячій літературі та критиці піднімалися питання денаціоналізації й асиміляції українських дітей та молоді. Головний акцент у низці розвідок, опублікованих в юнацькому журналі «Крилаті», падав на проблеми безкритичного засвоєння чужих звичаїв, відірваності української молоді від рідної землі, яку вона не знає, та формуванні образу краю лише 3 оповідань батьків [Бойківська 1964 : 2]. Ось тому в дитячій діаспорній літературі письменниками «покоління Ді-Пі» втілювався образ «Старого Краю», України, як вона запам'яталася. Адже, зазначав Г.Г.Гадамер, прив'язаність до історичної Батьківщини в еміграції реалізується через думки про неї: «Так, життя на вигнанні мусить бути пронизаним думкою про Батьківщчину, яку довелося покинути, й думкою про повернення - навіть тоді, коли про таке повернення $i$ думати годi» [Гадамер 2001 : 188]. 3 образом «Старого Краю» українські письменники діаспори пов’язували проблему пошуків власних коренів. Це визначало родинну тематику творів письменників канадського та американського діаспорних осередків, які широко послуговувалися сталими для української діаспори образами - «батьківський дім», «родина», «громада», «земля», «село».

Українські родини у творах це як переселенці зі «Старого Краю», так і громадяни нового, «Вільного Світу». Головно, що представниками першого $є$ старше покоління, натомість другого - діти, переважно другого чи третього покоління, народжених у країнах укорінення української еміграції. Через дитячі образи в літературі для дітей та юнацтва ставляться питання формування 
національної ідентичності українця в діаспорі. Проте українських письменників Канади й США цікавить також те, як діти українців справляються зі своєю двокультурною ідентичністю.

Образи дорослих зі «Старого Краю» виступають носіями ідеї українськості. Іноді автори не дають їм навіть імен. Їх портрет типовий. Оскільки вони ідентифікуються 3 вигнанцями зі своєї Батьківщини, що прагнуть відновити винесені 3 рідної землі традиції, мову, звичаї у своїх зустрічах із Чужим. У цьому сенсі слушно зауважував Е. Саїд: «...вигнанецьь гостро потребує відновити своє життя з уламків, і виражається иуе (...) в потребі відчути себе частиною відроджуваної нації чи носієм життєстійкої ідеологї̈» [Саїд 2003 : 255]. Тож роль старших в іншому - передати знання про Україну нащадкам, увиразнюючи тим самим їхній двокультурний характер ідентичності. Такими є взаємини дідусів 3 онуками Івасиком («Листування» Ганна Черінь), Лесиком («Що я можу зробити для України» С. Кузьменко), бабусі та Богданка («Бабунина казка» Т. Білецька), матерів 3 дітьми (Л. Храплива-Щур «Юрчиків сон», Р. Завадович «Грудка рідної землі»). У такий спосіб проводиться ідея безперервності роду та традицій, укорінення їх в новій «прибраній батьківщині».

Для старшого покоління «Старий Край» сполучений 3 історичною Батьківщиною в іiі конкретно-чуттєвих образах. Все, що пов’язано 3 рідним краєм, його історія, пам'ять про національно-визвольні змагання, війну, вигнання, традиції оприявлюються у текстах через спогади дідів та батьків, які діти переповідають, чим засвідчують свою культурну приналежність за походженням. У такий спосіб письменники формували моделі національної та особистої ідентифікації в багатокультурному просторі.

Тематично ці моделі пов’язані 3 представленням образу України в англомовному середовищі серед дітей інших національностей та вчителів шкіл (С. Парфанович «Військовий договір», Л. Храплива-Щур «Перший день у школі» зі збірки «Вітер 3 України», Іван Боднарчук «Михасева зустріч 3 Канадою», С. Кузьменко «Що я можу зробити для України»); популяризацією 
навчання дітей в українських школах й вивчення української мови (Ганна Черінь «Недільна школа для батьків» та «Листування», Л. Храплива-Щур «Юрчиків сон» зі збірки «Вітер з України»); дотримання українських традицій, зокрема носити вишиванку (Ганна Черінь «Зустрілися» зі збірки «Українські діти») та повернення до рідного краю (Іван Боднарчук «Придорожній хрест» зі збірки «Кладка», Р. Завадович «Грудка рідної землі»). Тут образ України у візії української молоді відкривається на рівні духовному, оскільки, за влучним спостереженням О. Пресіч, «Відсутність чіткого візуального образу України у свідомості украӥниів, народжених у Канаді, приводить до того, щуо етнічна Батьківщуина втрачає для них реальні територіально-культурні прикмети, перетворюючись на ментальний образ із розмитими міфологізованими конотаціями» [Пресіч $2014: 8]$.

Ментальний образ України в дитячих діаспорних творах письменників діаспори Канади й США є згустком знакових для української еміграції топосів, подій, символів: небо, поле, ставки, білі хати, пташки, квіти, вишні, мова Шевченка, Київ, Канів, Львів, Чернігів, Полтава, Кривий Ріг. Через ці образи письменники тлумачили Україну як багату й невільну водночас, вкладаючи ці міркування в уста своїх юних героїв, як це можемо бачити в С. Парфанович («Військовий договір») та Л. Храплива-Щур («Перший день у школі»). Природні ресурси - це добро й джерело всіх іï нещасть: «...Україна - великий простір урожайного чорнозему. На неї споконвіку зазіхали всі сусіди. В Украӥні багаті поклади мінералів, великі фабрики. Земля $i$ промисел» [Парфанович 1967 : 8]. Зрештою, такі ідентифікації з етнічною Батьківщиною як Іншою у порівнянні до тої, громадянином якої є, розкривали у творах модель поведінки української молоді в діаспорі - прислужитися Україні, що в етичному плані означало пізнати себе через Іншого, відкриту власну особисту ідентичність.

Самоповага, турбота та рівність у концепції П. Рікера це три вияви етичної мети в інтерпретації самого себе. Як стверджував філософ: «Я не можу поважати себе, не поважаючи іншого як мене самого» [Рікер 2002 : 232]. У 
літературі для дітей та юнацтва письменників діаспори Канади й США впізнаваність себе йде через турботу про гурт, громаду. 3 цих позицій письменники відкривали українську молодь діаспори через дві ролі: бікультурала та маргінала.

«Погано бути ніким!» - таку ідею несе твір «А хто ти?» Ганни Черінь зі збірки «Українські діти» [Черінь УД : 39]. Тут авторка викриває тих українців, які соромляться свого походження, змінюючи свої україномовні прізвища. Таким зображений хлопчик Михась Лавріненко, який став іменуватися Майком Леврі. А в іншому своєму творі «Листування» письменниця засуджує вживання мовних покручів, до яких вдавався герой Івасик, замінюючи українські слова англійською мовою. Українськість є для обох хлопців тим Іншим, для якого треба змінитися в собі аби почати поважати себе як Іншого. Турбота про Іншого у творах Ганни Черінь реалізується через вивчення й використання української мови дітьми в еміграції, оскільки у тому письменниця вбачає запоруку згуртовування українців: «Так, через листування міциим ланц̧югом єднаються молоді украӥнці в цүілому світі, $i$ Івась почуває себе важливою ланкою в изім ланц̧юзі» [Черінь 1966 : 51].

Схожу ідею містить оповідання Івана Боднарчука «Олесів іспит», в якому забуття рідної мови інтерпретується як розрив зі Своїм під впливом Чужого. Тут проблема денаціоналізації порушується через опозицію місто батьківський дім, де одне є тілесним, а інше - місцем душевним. Місто у творі - це шалений темп, холод, камінь, а батьківський дім - затишок, любов, допомога в біді, турбота. Через протиставлення цих образів письменник відобразив втрату культурної й особистої ідентичності Олеся, який цурається свого українського роду: «Місто шуміло, диміло, щуось немов виварювало. $A$ батьківський дім десь далеко, на протилежному березі озера, немов обірвався, відчалив. Олесь чув, як з кожним днем він віддалявся, як дні ставали смутні, а ночі грізні й тривожні. Віддалявся рідний дім і рідні в ньому мати, батько, сестричка» [Боднарчук 1993 : 49]. Усвідомлення своєї інакшості в багатокультурному світі йде в Івана Боднарчука через відчуття глибокого 
зв’язку з мовою та своєю родиною: «До рідної матінки тільки по-рідному треба писати. Чужим словом до ї̈ серияя не доберешся, не докличешся» [Боднарчук 1993 : 50].

Своєрідним етичним жестом турботи про Україну та закликом до готовності служити українській громаді в еміграції $\epsilon$ інший твір Івана Боднарчука - повість для молоді «У дорозі життя», відзначена на конкурсі Об’єднання працівників літератури для дітей та молоді ім. Л. Глібова в 1985 році. У ній письменник подав своє бачення у дискусії навколо патріотизму української молоді Канади, узагальнено сформульовану А. Горохович так: «Як погодити патріотизм украӥнський, зв'язок наш з культурою Украӥни з любов'ю до канадської землі, де ми народились?» [Горохович 1990 : 79]. Художні рішення Івана Боднарчука - це два вибори української молоді діаспори. Перший - конформізм, спричинений асиміляцією культури Чужого. На позначення цього письменник вдається до зображення бітнцитва (beat generation - «втрачене покоління»), неформального молодіжного руху минулого століття. До нього приєднується головний герой твору українець за походженням Денис, який втратив зв’язок із усім рідним (родиною, громадою, країною, мовою) та став на шлях волоцюги. Проте через образ Іванки, подруги дитинства юнака, письменник викриває бітників: «Це - збоченціi. Люди без майбутнього. Майже всі вони наркомани (...) Ідея бітників - цฺе утопія. Людина вже виросла з того, до чого вони повертаються» [Боднарчук 1986 : 21-22]. Образ Іванки - $є$ уособленням другого вибору, пов’язаного 3 прийняттям традиційних культурних цінностей держави, проживання та усвідомлення себе частиною цілого, української громади, відповідальність за яку несе кожен їі член. Таких письменник називає свідомою українсько-канадською молоддю, розкриваючи у творі образ бікультурала. Цьому він присвятив другу частину повісті. Тут він зобразив українську громаду в Канаді через діяльність Інституту ім. Г. Сковороди, котру після численних життєвих перипетій герої Денис та Іванка очолюють, означивши свою українську ідентичність. 
Образ Канади в Івана Боднарчука - це образ країни вільних можливостей та новий дім для українців. Таку позицію автор висловлює через представників старшого покоління батьків Іванки, уособлюючи їх зі скитальцями, які на чужині будують свою батьківщину: «Як изе не вдома? Я ж у свойй хаті. А у своїй хаті - своя правда... У моїй хаті святі образи, своя мова - моя Україна. Хата моя належить до своєї громади, а громада до спільноти, а спільнота живе Украӥною - живущцою Украӥною, байдуже, як далеко вона від нас» [Боднарчук 1986 : 13]. У такий спосіб чужий простір набирає обрисів Свого, своєрідною моделлю чого виступає образ Канадської України. Цей образ не є витвором уяви Івана Боднарчука. Як писав Яр Славутич у своїх спогадах, «Канадська Украӥна живе з 1891-ого року!» [Славутич 1988 : 8]. Від тоді українці змогли зберегти свою культурну ідентичність, розбудовуючи цілі поселення від Едмонтону до Вінніпегу зі своїми школами, університетами, періодикою тощо. Тому причина політика багатокультурності Канади, що за виразом В. Леника, «здавна славилася свободою індивідуальности та етнічних груп». «I не дивно, - далі зазначає дослідник, - більшість громадян Канади затримали до сьогодні свої старі традиційні звичаї, свою культуру» [Леник 1994 : 176-177]. Цю тяглість культури Іван Боднарчук зафіксував у своїх творах, де Канадська Україна наповнена українським простором: фермами (замінником села), школами, церквами, інституціями, народними домами.

Українські топоси в чужому просторі не лише ставали свідченнями пам’яті про рідний край та виявом любові до нього. Вони в Івана Боднарчука уособлювалися 3 волею, яку українці здобули в Канаді. У його оповіданні «Михасева зустріч 3 Канадою» в очах емігрантів ця країна - то «..великий простір, а на ньому всякому воля» [Боднарчук 1956]. А в іншому своєму оповіданні «Галина про Україну» він протиставляє Україну та Канаду, уособлюючи одну $з$ неволею, другу - волею, якій засвідчує свою дяку: «Нема то кращуе, як у нас в Канаді, де людина може бути сама собою, й не боїться, щуо обсотає тебе павук. Пошануймо ц̧ю воленьку!» [Боднарчук 1993 : 55]. 
Якщо з Канадою пов'язаний образ Канадської України, то топоси США ідентифікуються за місцем проживання або відпочинку героїв творів для дітей, написаних письменниками діаспори американського осередку. Це - Нью-Йорк, Каліфорнія, Флорида, Міннесота, Ніагара чи Лисяче озеро. Проте образ Америки як i Канади у творах українських діаспорних письменників наповнений значенням волі, зосібна у творах Т. Білецької «Бабунина казка», Олекса Кобця «Про хлопчика Івася, що вміє сам себе оборонити», Леоніда Полтави «Малий індіянин», Ганни Черінь «У що будемо бавитись?» (збірка «Українські діти»). Тому важливим компонентом ії культурного образу тут виступає статуя Свободи на о. Бедлоу - «Свобода, що осяює світ». У такий спосіб персонажі творів рефлектують над культурною ідентичністю, яка в США хоча й розуміється інакше, але не становить загрозу для існування різних народів.

Статуя Свободи в оповіданні «Бабунина казка» Т. Білецької уособлює світло і волю, а власне Америка несе надію й стає місцем для прихистку тих, хто зазнає переслідувань через національну й культурну приналежність. Увиразненню цієї ідеї сприяє введення до структури твору казки про добру ворожку зі смолоскипом в руці, яка забезпечує порятунок «нескореним», переслідуваних охоронцями чародія-лиходія. Письменниця у такий спосіб не лише міфологізує український досвід вигнанця. Тут же вона зафіксувала непрості реалії побуту новоприбулих: важка праця, проживання біля надземної залізниці та самотність. Утім, вона засвідчила й прагнення українців жити вільно, що в творі тяжіє до категорій духовних: «Mи - нескорені, ті, щэо вчились пити тільки з чистої криниці, відділяти зерно від полови і ніколи перед ніким не гнути хребта» [Білецька 1973 : 12].

Ідентифікація українця в США як рівного серед інших народів простежується у віршованому оповіданні Леоніда Полтави «Малий індіянин». Нью-Йорк тут уявлявся не лише велетенським містом, а й багатокультурним всесвітом. Ось так ідея космополітизму завважується в міркуваннях уродженця міста й етнічного українця [Полтава $1968: 13]$ : 
Та я ж народився в Нью-Йорку, у Штатах!

Мій тато і мама, і я-украӥнці,

Але у Америці ми не чужинці;

Ось може ви шведи, англійщі, еспаниі,

А всі ми - американиі!

Позитивні засади американської цивілізації проектуються в оповіданні «Про хлопчика Івася, що вміє сам себе оборонити» Олекса Кобця на Україну. Америка тут оцінюється як «найбагатша $i$ найвільніша земля на світі» [Кобець 1967 : 11], тому розповсюдження іiї демократичних процесів в Україні сприятиме іiі розквіту. У такий спосіб Олекса Кобець, 3 одного боку, засуджуючи окупацію України «безбожними комуністами», порушував питання загрози втрати культурної ідентичності українцями в рідному краю. Але водночас окреслив способи іiі збереження в чужому світі. Це в письменника досягається через модель спілкування носіїв різних культур - американських й українських дітей.

Таким чином, у своїх творах для дітей та молоді письменники поєднують два культурні світи - канадсько-американський та український. 3 одного боку, так репрезентувалися реалії зарубіжжя, а 3 іншого, - представлявся ментальний образ України. Тому тематичні пошуки українських письменників Канади й США охоплювали проблеми гуртування українців на чужині, розщеплення особистості під впливом асиміляції, безперервності роду та традицій, служіння для України.

\section{БІБЛІОГРАФІЯ}

Білецька 1973 - Бабунині казки. Торонто : ОПДЛ - Нашим дітям, 1973. $63 \mathrm{c}$.

Боднарчук 1956 - Боднарчук I. Михасева зустріч з Канадою // Соняшник. 1956. № 6. [Б. c.].

Боднарчук 1986 - Боднарчук I. У дорозі життя : повість 3 життя еміграційної молоді. Торонто, Канада : ОПДЛ - Нашим дітям, 1986. 72 с. 
Боднарчук 1993 - Боднарчук I. За Збруч // Боднарчук I. За Збруч. Торонто : Фундація ім. Івана Боднарчука, 1993. С. 9-26.

Бойківська 1964 - Бойківська I. Вплив чужого світу на українську молодь // Крилаті. 1964. № 4. С. 2-3.

Вальденфельс 2002 - Вальденфельс Б. Топографія Чужого. Студії до феноменології Чужого. К. : ППС, 2002, 2004. 206 с.

Гадамер 2001 - Гадамер Г. -Г. Герменевтика і поетика. К. : Юніверс, 2001. 278 c.

Горохович 1990 - Горохович А. Батьки і діти. Вінніпег-Торонто : Світова Координаційна Виховно-Освітня Рада, 1990. 176 с.

Кобець 1967 - Кобець О. Про хлопчика Івася, що вміє сам себе оборонити // Крилаті, 1967. № 11 (листопад). С. 11-12.

Леник 1994 - Леник В. Українці на чужині або репортажі з далеких доріг. Львів: «Червона калина», 1994. - 335 с.

Парфанович 1967 - Парфанович С. Військовий договір (уривок з повісті «Карусь і ми») // Крилаті. 1967. № 9 (вересень). С. 7-8.

Полтава 1968 - Полтава Л. Малий індіянин. Нью-Йорк : ОПДЛ - Нашим дітям, 1968. - 16 c.

Пресіч 2014 - Пресіч О. В. Повоєнна українська проза в Канаді : проблемно-тематичні, жанрово-стильові пошуки. Автореф. дис. ... канд. філол. наук. К., 2014. 18 с.

Рікер 2002 - Рікер П. Сам як інший. Вид. 2-ге / пер. В. Андрушко, О. Сирцова. Київ : Дух і літера, 2002. 456 с.

Саїд 2003 - Саид Э. Мысли об изгнании // Иностранная литература. 2003. № 1. С. 252-262.

Славутич 1988 - Славутич Яр. У вирі багатокультурності. Спогади учасника. Едмонтон : Видавництво «Славута», 1988. 224 с.

Черінь УД - Черінь Г. Українські діти : оповідання для дітей / Ред. Є. Рослицький. Торонто : Видання комісії шкільництва. [Б. р.]. 70 с. 
Черінь 1966 - Черінь Г. Листування. Джерзі Ситі - Нью-Йорк : Видання Українського Народного Союзу, 1966. 54 с. 